Research Article

\title{
Composition of the Essential Oil Thymus schimperi and Evaluation of Its Acute and Subacute Toxicity in Wistar Albino Rats: In Silico Toxicity Studies
}

\author{
Fentahun Adane $\mathbb{D}^{1},{ }^{1}$ Kaleab Asres, ${ }^{2}$ Wondwossen Ergete, ${ }^{3}$ Samuel Woldekidan, ${ }^{4}$ \\ Abiy Abebe, ${ }^{5}$ Boki Lengiso, ${ }^{6}$ and Girma Seyoum $\left(10^{1}\right.$ \\ ${ }^{1}$ Department of Anatomy, College of Health Sciences, Addis Ababa University, Addis Ababa, Ethiopia \\ ${ }^{2}$ Department of Pharmaceutical Chemistry \& Pharmacognosy, College of Health Sciences, Addis Ababa University, \\ Addis Ababa, Ethiopia \\ ${ }^{3}$ Department of Pathology, School of Medicine, College of Health Sciences, Addis Ababa University, Addis Ababa, Ethiopia \\ ${ }^{4}$ Ethiopian Public Health Institute, Biomedical and Clinical Research Team, \\ Traditional and Modern Medicine Research Directorate, P.O. Box 1242, Addis Ababa, Ethiopia \\ ${ }^{5}$ Directorate of Traditional and Modern Medicine Research, Ethiopian Public Health Institute, P.O. Box 1242, \\ Addis Ababa, Ethiopia \\ ${ }^{6}$ Ethiopian Public Health Institute, National HIV/AIDS and TB Directorate, P.O. Box 1242/5654, Addis Ababa, Ethiopia
}

Correspondence should be addressed to Girma Seyoum; girma91@yahoo.com

Received 24 February 2021; Revised 13 July 2021; Accepted 14 July 2021; Published 26 July 2021

Academic Editor: Muhammad Nabeel Ghayur

Copyright (C) 2021 Fentahun Adane et al. This is an open access article distributed under the Creative Commons Attribution License, which permits unrestricted use, distribution, and reproduction in any medium, provided the original work is properly cited.

\begin{abstract}
Background. In Ethiopian traditional medicine, the aerial part of Thymus schimperi is widely used to treat diseases such as gonorrhea, cough, liver disease, kidney disease, hypertension, stomach pain, and fungal skin infections. However, there is insufficient investigation on the toxic effect of the essential oil of T. schimperi. The aim of this study was, therefore, to evaluate the acute, subacute, and in silico toxicity of Thymus schimperi essential oil in the Wistar albino rats. Method. Essential oil of the aerial part of T. schimperi extracted by hydrodistillation was analyzed by GC-MS. The oil was subjected to toxicity studies. In the acute toxicity study, rats were randomly divided into seven groups $(n=5)$. The control group received only distilled water with $2 \%$ of tween 80, whereas the experimental groups received single doses of 300,600,900, 1200, 1500, and $2000 \mathrm{mg} / \mathrm{kg}$ of the oil. In the subacute toxicity study, rats were randomly divided into four groups $(n=10)$. The control group received distilled water with $2 \%$ of tween 80 , whereas the experimental groups received $65 \mathrm{mg} / \mathrm{kg}, 130 \mathrm{mg} / \mathrm{kg}$, and $260 \mathrm{mg} / \mathrm{kg}$ of the oil orally for 28 days. At the end of the experiment, blood samples were collected for hematology and clinical chemistry evaluation. Gross pathology and histopathology of the liver and the kidneys were also evaluated. For the in silico toxicity study, PubChem CID numbers of GC-MS identified bioactive compounds in the essential oil of T. schimperi obtained from PubChem. Chemdraw (8.0) was used to construct two-dimensional structures of the compounds. The Swiss ADMET web tool was used to convert the two-dimensional structures into a simplified molecular-input line input system (SMILES). In addition, the toxicity parameters were predicted via vNN and ADMET servers. Results. In this study, the $\mathrm{LD}_{50}$ of the essential oil of T. schimperi was found to be $1284.2 \mathrm{mg} / \mathrm{kg}$. According to the World Health Organization, the oil is classified as moderately hazardous in its oral administration. In the subacute toxicity study, rats showed no significant changes in behavioral indices, gross pathology, body weight, biochemical, and most hematological parameters. However, hematological profiles showed a significant decrement in WBC counts and a significant increment of MCV in high dose $(260 \mathrm{mg} / \mathrm{kg})$ groups as compared to the control group. Furthermore, no significant differences were observed between the control and essential oil-treated groups, observed in the gross histopathology of the liver and the kidneys. In the in silico toxicity study, all compounds derived from the essential oil showed no cardiac toxicity (h-ERG Blocker), AMES (Ames Mutagenicity), and cytotoxicity via ADMET and vNN-ADMET toxicity predictors. However, by using these servers, about $8.6 \%$ of the compounds showed hepatotoxicity, only $3.45 \%$ caused drug-induced liver injury, and only $1.75 \%$ were potentially toxic to the mitochondrial membrane. Conclusion. From the results of this study, oral administration of the essential oil T. schimperi up to a
\end{abstract}


dose of $130 \mathrm{mg} / \mathrm{kg}$ is not harmful. However, in the high-dose $(260 \mathrm{mg} / \mathrm{kg})$ group, the WBC count was significantly decreased and the MCV was significantly increased. In the in silico toxicity study, most of the components of the oil were found to be nontoxic, although a few of the compounds showed hepatotoxicity and mitochondrial membrane potential toxicity. It is, therefore, essential to conduct chronic toxicity of the essential oil as well as its components, which showed toxicity in the in silico study before using preparations containing the essential oil of T. schimperi.

\section{Introduction}

The genus Thymus contains about 350 species widely distributed in equatorial regions of the world [1]. In different parts of the world, T. schimperi (thyme) extracts are traditionally used orally to treat dyspepsia and other gastrointestinal disturbances, bronchitis, pertussis, laryngitis, tonsillitis, and coughs due to colds $[2,3]$. Topical applications of thyme extracts have been used in the treatment of minor wounds, common cold, disorders of the oral cavity, and antibacterial agents in oral hygiene [3].

Members of the genus are one of the most widely used medicinal plants in Ethiopia, mainly because of their antimicrobial activity [2]. Both T. schimperi and T. serrulatus are locally known as "Tosign," and their leaves are used as spices in various food products and medicines [4]. In Ethiopia, T. schimperi is used in a variety of forms [3]. The fresh or dried leaves are used locally as condiments and tea [5], in the preparation of "berbere" (pepper powder) and "shirro" (bean/ pea powder) [6] and for the preparation of metata ayb (fermented cottage cheese) [7]. In traditional medicine, T. schimperi is used to treat different diseases like gonorrhea, cough, liver disease, renal diseases, hypertension [3], stomach pain [8], kidney problems [9], and dermal fungi [10].

T. schimperi contains about $1.0 \%-2.5 \%$ essential oil. The composition of the essential oil fluctuates depending on the chemo type of the plant. The principal components of T. schimperi are thymol and carvacrol (up to $64 \%$ of the oil), along with linalool, $p$-cymol, cymene, hymene, $\alpha$-pinene, apigenin, luteolin, and 6-hydroxyluteolin glycosides, as well as di-, tri-, and tetra-methoxylated flavones [11].

Even though the leaves of T. schimperi are widely used in traditional medicine, there is not enough investigation on the toxic effects of the essential oil of the plant. Therefore, the purpose of this study was to evaluate the acute and subacute as well as in silico toxicities of the essential oil of T. schimperi in Wistar albino rats.

\section{Materials and Methods}

2.1. Plant Material. Fresh leaves of T. schimperi were collected in March 2019 from around Goba city, $400 \mathrm{~km}$ southeast of Addis Ababa, and $150 \mathrm{~km}$ east of Shashemene in Oromia Region. The plant material was authenticated by a botanist at the Ethiopian Public Health Institute (EPHI) where it was deposited (Collection number: $\mathrm{HH}-001$ ) for future reference.

2.2. Study Animals. Wistar albino rats, 8 to 10 weeks of age, obtained from the Ethiopian Public Health Institute (EPHI) breeding unit, were utilized for this study. The female rats were nulliparous and nonpregnant. Same-sex rats were divided into experimental and control groups in a standard cage with five animals per group $(n=5)$ and held under standard conditions (at a temperature of $20^{\circ} \mathrm{C}\left( \pm 2^{\circ} \mathrm{C}\right)$, with a normal 12-hour light/12-hour dark cycle). All the experiments were conducted following the internationally accepted laboratory animal use and care guidelines [12]. In addition, the Institutional Review Board (IRB) of the College of Health Sciences, Addis Ababa University, approved the protocol. Animals were acclimatized for one week before the commencement of the study and were provided with water and food pellets ad libitum before and until the end of the experimental period.

2.3. Essential Oil Distillation. Fresh leaves of T. schimperi $(1 \mathrm{~kg})$ were extracted by hydrodistillation using a Clevengertype apparatus. The oil obtained was stored in a sealed amber-colored vial in a refrigerator at $-10^{\circ} \mathrm{C}$ until it is used for the study.

\subsection{Analysis of the Essential Oil}

2.4.1. GC Analysis. Separation was carried out on a Shimadzu gas chromatograph, model GC-14A, fitted with a supelcowax $10 \quad(30 \mathrm{~m} \times 0.25 \mathrm{~mm}, 0.2 \mu \mathrm{m}$ film thickness $)$ fused silica column. The oven temperature was programmed as follows: $70^{\circ} \mathrm{C}(5 \mathrm{~min}), 70-180^{\circ} \mathrm{C}\left(5^{\circ} \mathrm{C} / \mathrm{min}\right), 180-240^{\circ} \mathrm{C}$ $\left(10^{\circ} \mathrm{C} / \mathrm{min}\right)$, and $240^{\circ} \mathrm{C}(10 \mathrm{~min})$. Helium was used as a carrier gas at a flow rate of $1 \mathrm{ml} / \mathrm{min}$ and with a split ratio of $82: 1$. Injector and Flame Ionization Detector (FID) temperatures were $210^{\circ} \mathrm{C}$ and $260^{\circ} \mathrm{C}$, respectively.

2.4.2. GC-MS Analysis. Qualitative GC-MS analyses were carried out using the Mass Lab VI.1 system equipped with an FI 8000GC. A Supelcowax $10(30 \mathrm{~m} \times 0.25 \mathrm{~mm}, 0.2 \mu \mathrm{m}$ film thickness) fused silica column was used with oven temperature programming: $60^{\circ} \mathrm{C}(5 \mathrm{~min})$ and with the injector temperature at $210^{\circ} \mathrm{C}$. Quantitative data were obtained by flame ionization detection and electronic integration without using FID response factors. The experiments were not replicated. The compounds were identified by coinjection (GC) with authentic samples and by computerized matching of the acquired mass spectra with library spectra (MS).

2.5. Acute Toxicity. Acute toxicity evaluation was performed in compliance with OECD 425 research guidelines [13]. Healthy female Wistar rats were fasted overnight but allowed access to water ad libitum and divided into seven 
groups $(n=5)$ randomly. Distilled water with $2 \%$ of tween 80 was provided to the first group (control group). The other six classes were treated orally with single doses of $T$. schimperi essential oil at 300,600,900, 1200, 1,500, and 2,000 mg/kg, respectively. Doses were selected after performing pilot studies. All the treatments were provided by force-feeding. Animals were examined for symptoms of toxicity and body weight, as well as mortality for 14 days. During the first 3 hours after essential oil administration, toxicity signs and symptoms were observed in individual cages and then evaluated regularly throughout the study [13]. The LD50 value was measured according to the rats' mortality observed within 14 days. On Day 15, all surviving animals were sacrificed, internal organs were excised, and organ weights were measured.

2.6. Subacute Toxicity. A subacute toxicity study was carried out in compliance with the recommendations of OECD 425 research guidelines [13]. The animals were randomly divided into four groups of 10 rats per group, each group containing five male and five female rats. The oil was administered by gavage orally in doses of $65 \mathrm{mg} / \mathrm{kg}$, $130 \mathrm{mg} / \mathrm{kg}$, and $260 \mathrm{mg} / \mathrm{kg}$ for 28 consecutive days, whereas only distilled water with $2 \%$ of tween 80 was given to the rats in the control group. The doses specified were based on the acute toxicity report LD50 value of $1284.2 \mathrm{mg} / \mathrm{kg}$. Signs of toxicity and mortality were monitored regularly, with changes in body weight and weekly measurements of food and water intake. At the end of the study, animals were fasted overnight, diethyl ether anesthetized, and blood samples collected by cardiac puncture. Heparinized blood samples were used for the determination of hematological parameters. Nonheparinized tubes were used to analyze blood chemistry, while blood glucose was determined using fluoride tubes. The liver and the kidneys were removed and immediately weighed after dissection.

2.6.1. Hematological and Biochemical Analyses. Ethylenediaminetetraacetic acid (EDTA) was used as a processor of blood samples in test tubes. Hematological parameters were determined on a hematology analyzer (SYSMEX XT-1800i, SYSMEX CORPORATION, Japan). White blood cell count (WBC), red blood cell count (RBC), hemoglobin concentration (HGB), hematocrit (HCT), mean corpuscular volume (MCV), mean corpuscular hemoglobin concentration (MCHC), and platelet count (PLC) were evaluated. For biochemical analysis, blood samples were allowed to stand for $3 \mathrm{hrs}$ in plain test tubes for full clotting and centrifuged for $15 \mathrm{~min}$ at $5000 \mathrm{rpm}$ using a benchtop centrifuge (Humax-k, Human-GmbH, Germany). The plasma was drained and transferred to other clean vials, and the serum was kept at $-20^{\circ} \mathrm{C}$ until clinical biochemistry measurements were done. The concentrations of alanine aminotransferase (ALT), aspartate aminotransferase (AST), urea, albumin, and creatinine were automatically determined using Cobas Integra-400 plus Analyzer (Roche Diagnostics, Japan).
2.6.2. Organ Weight Measurements and Tissue Samples. After assessing body weight, all experimental animals were sacrificed on day 29, and the target organs were taken. The organs were then kept for a few minutes in $1 \%$ normal saline to clean any extraneous tissues and weighed with precision balance. The tissue samples taken from the liver and the kidneys were placed in a test tube with $10 \%$ formalin buffered for $24 \mathrm{hrs}$ and rinsed overnight under tap water. The fixed tissues were then dehydrated and washed with ethanol and xylene, respectively. In addition, it was infiltrated with molten paraffin wax and embedded in paraffin blocks. The blocks were sectioned at a thickness of 5-6 $\mu \mathrm{m}$ using Leica rotary microtome (Leica RM 2125 RT, China, checked in Germany). Ribbons of the tissue sections were gently collected using forceps and placed on the surface of a water bath at $30-40^{\circ} \mathrm{C}$ before they were placed over the tissue. The slides were then mounted in slide racks and placed overnight in an oven at a temperature of $20-40^{\circ} \mathrm{C}$ to make it easy for the specimens to be fixed on the glass slides. The thin sections then underwent different stages of xylene and alcohol treatment and stained with hematoxylin and eosin [14].

2.6.3. Light Microscopy and Photomicrography. Stained tissue portions of the liver and the kidney were carefully examined in a binocular compound light microscope (Olympus CX41, Japan). Sections of tissue from the treated groups were examined for any signs of histopathological changes. Photomicrographs of selected slides from both the treated and the control group were taken using an automated digital photo camera (Evos XI, China), under a magnification of $\times 40$ and $\times 20$, respectively.

2.6.4. Data Processing and Analysis. All data presented with numbers were analyzed by SPSS statistical software. All values have been expressed in mean \pm SEM (standard error of the mean). Treatments over time were compared by using a one-way analysis of variance (ANOVA) among control and treated groups followed by Dunnett's $t$-test to determine the significance level. Statistical significance was considered at $P<0.05$.

2.7. Ethical Consideration. In this study, the Institutional Review Boards of the College of Health Sciences, AAU, and EPHI approved all procedures followed.

2.8. In Silico Toxicity Prediction. Compounds present in the essential oil of T. schimperi have been identified by GC-MS. The PubChem CID number was obtained from PubChem [15]. Chemdraw (8.0) [16] was used to build two-dimensional structures (Table 1). The Swiss ADME web tool was used to convert the two-dimensional structures into a simplified molecular-input line input system (SMILES) that can be analyzed by servers for toxicity prediction [17].

Toxicity profiles are as follows: hERG potassium channel inhibition (cardiotoxicity), H-HT (Human Hepatotoxicity), and AMES (Ames Mutagenicity) distribution were predicted 
TABLE 1: Structure of compounds from Thymus schimperi essential oil.

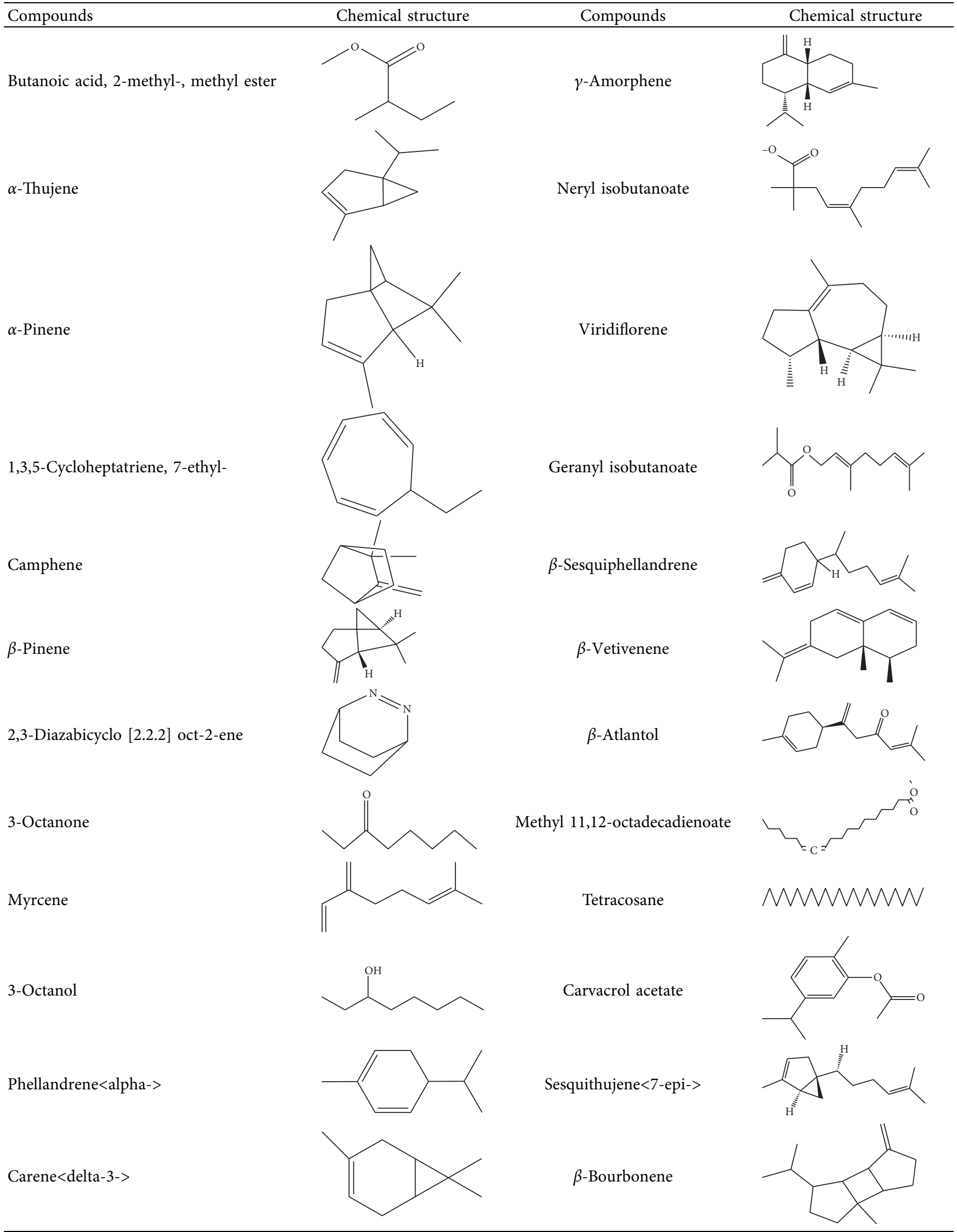


TABLE 1: Continued.

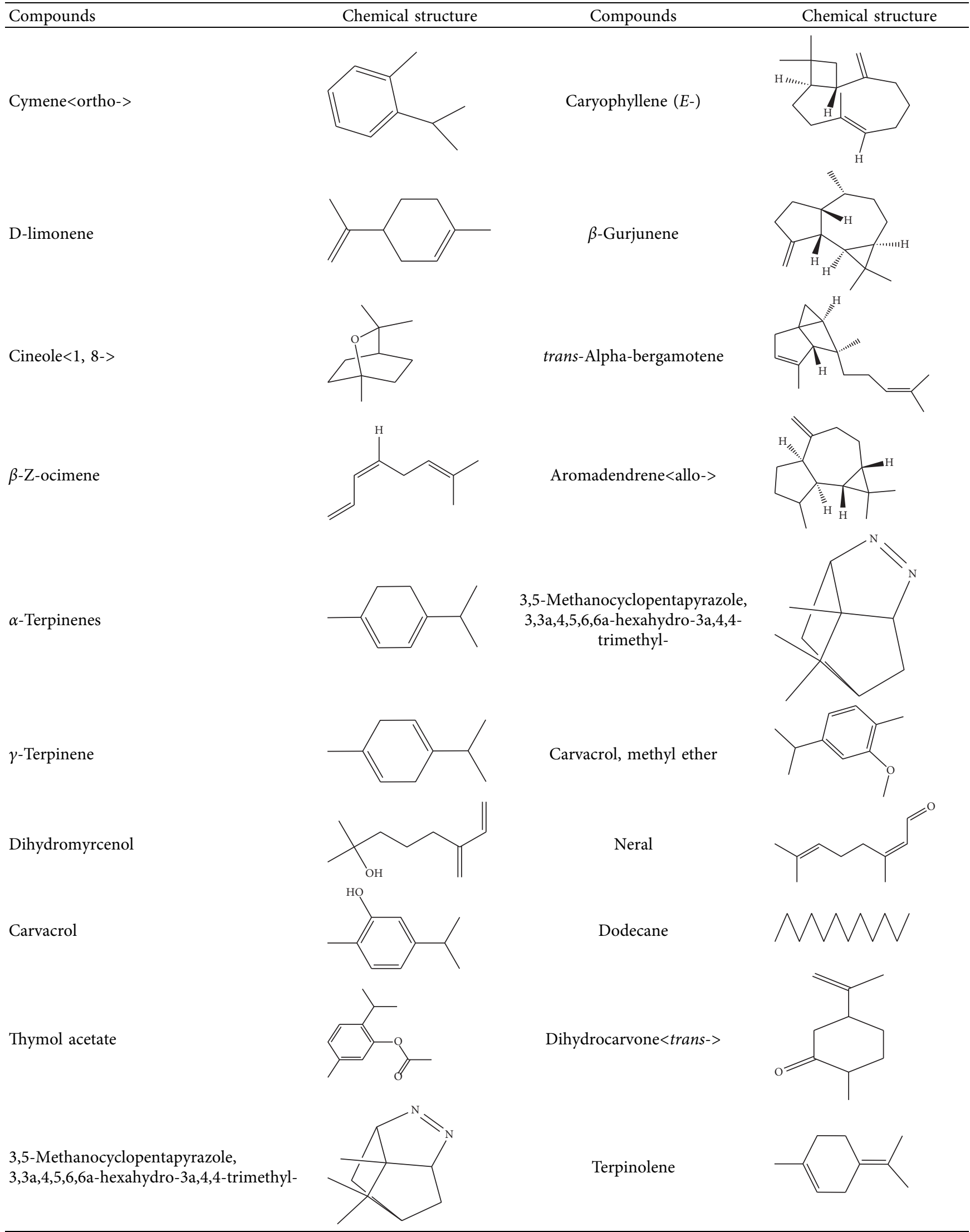


TABLE 1: Continued.

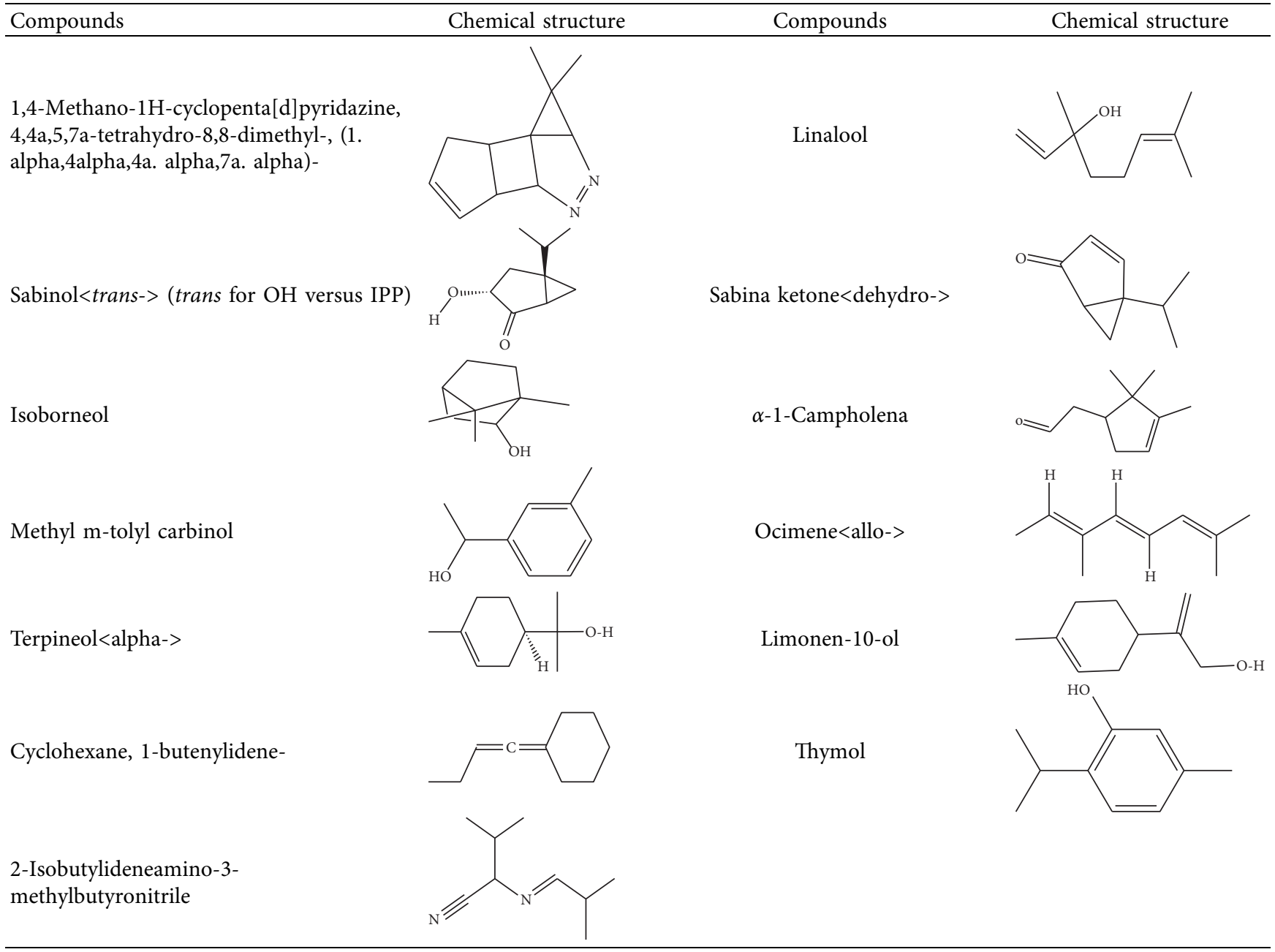

using the ADMET (Absorption, Distribution, Metabolism, Execration, and Toxicity) server [18]. Drug-induced liver injury (DILI), mitochondrial membrane potential (MMP) toxicity, and cytotoxicity parameters were predicted via $\mathrm{vNN}$ server [19].

\section{Results}

3.1. Chemical Composition Analysis. Percentage yield of the essential oil of the fresh leaves of T. schimperi obtained by hydrodistillation was $1.39 \%(\mathrm{w} / \mathrm{w})$. The oil was dark yellowish with a strong spicy scent. Qualitative and quantitative analyses carried out by GC/MS and GC identified 57 compounds representing $88.75 \%$ of the total essential oil. Results of the GC/MS analysis are summarized in Table 2, and GC chromatogram of the oil is depicted in Figure 1. As shown in Table 1, the major constituents of the oil were carvacrol (49.90\%), thymol (10.64\%), o-cymene $(8.54 \%)$, $\alpha$-terpinene $(4.5 \%)$, linalool $(2.51 \%)$, and 3-octanol $(2.48 \%)$.

The result of acute toxicity of $T$. schimperi essential oil given orally in single doses is shown in Table 3 . Starting at a dose of $900 \mathrm{mg} / \mathrm{kg}$ of the essential oil, the rats showed signs of toxicity, such as hypoactivity, piloerection, and convulsion including death. Mortality was observed in 900, 1200,
1500 , and $2000 \mathrm{mg} / \mathrm{kg}$ groups with $20 \%, 20 \%, 80 \%$, and $100 \%$ deaths, respectively (Table 3 ). The approximate LD50 obtained from the acute toxicity study was $1,284.2 \mathrm{mg} / \mathrm{kg}$. There was a significant decrease in body weight in $900 \mathrm{mg} / \mathrm{kg}$ and $1200 \mathrm{mg} / \mathrm{kg}$ treated groups as compared to the control group at day 7 on the acute toxicity study $(P<0.05)$. In addition, on day 14 , body weight has significantly decreased in $600 \mathrm{mg} / \mathrm{kg}, 900 \mathrm{mg} / \mathrm{kg}$, and $1200 \mathrm{mg} / \mathrm{kg}$ treated groups $(P<0.05)$ as compared to the control group. Similarly, body weight has significantly decreased in the $1200 \mathrm{mg} / \mathrm{kg}$ treated group as compared to $300 \mathrm{mg} / \mathrm{kg}$ treated group $(P<0.05)$. Nonetheless, treatment groups $(1500 \mathrm{mg} / \mathrm{kg}$ and $2000 \mathrm{mg} /$ $\mathrm{kg}$ ) were not included in the analysis as these groups had too few and no living rats, respectively. Furthermore, the weights of the kidney and the liver significantly increased in treatment groups (900 mg/kg and $1200 \mathrm{mg} / \mathrm{kg}$ ) as compared to the control group (Table 4).

3.2. Subacute Toxicity Study. In the subacute toxicity study, rats were randomly assigned to four groups, each of the groups containing 10 rats $(5 \mathrm{M}$ and $5 \mathrm{~F})$. Rats in the control group received distilled water with $2 \%$ of tween 80 , while the experimental groups received $65 \mathrm{mg} / \mathrm{kg}, 130 \mathrm{mg} / \mathrm{kg}$, and 
TABLE 2: Composition of the essential oil of the fresh leaves of Thymus schimperi.

\begin{tabular}{|c|c|c|c|c|}
\hline No. & Compounds & Percent & Ret. time & Ret. index \\
\hline \multirow{7}{*}{1} & Butanoic acid, 2-methyl-, methyl ester & 0.05 & 3,787 & 712 \\
\hline & $\alpha$-Thujene & 0.34 & 7,436 & 921 \\
\hline & $\alpha$-Pinene & 0.12 & 7,585 & 925 \\
\hline & 1,3,5-Cycloheptatriene, 7-ethyl- & 0.03 & 7,861 & 936 \\
\hline & Camphene & 0.03 & 7,939 & 939 \\
\hline & $\beta$-Pinene & 0.05 & 8,640 & 974 \\
\hline & 2,3-Diazabicyclo[2.2.2] oct-2-ene & 0.02 & 8,818 & 977 \\
\hline \multirow[b]{2}{*}{2} & 3-Octanone & 1.04 & 8,889 & 980 \\
\hline & Myrcene & 0.58 & 9,048 & 987 \\
\hline \multirow{3}{*}{3} & 3-Octanol & 2.48 & 9,213 & 993 \\
\hline & $\alpha$-Phellandrene & 0.24 & 9,334 & 999 \\
\hline & $\delta$-3-Carene & 0.80 & 9,638 & 1012 \\
\hline \multirow{4}{*}{4} & $o$-Cymene & 8.54 & 9,838 & 1020 \\
\hline & D-Limonene & 0.30 & 9,935 & 1024 \\
\hline & 1-8-Cineole & 0.39 & 9,973 & 1026 \\
\hline & $\beta$-Z-Ocimene & 0.39 & 10,166 & 1034 \\
\hline \multirow{4}{*}{5} & $\alpha$-Terpinene & 4.53 & 10,661 & 1055 \\
\hline & $\gamma$-Terpinene & 0.28 & 10,860 & 1064 \\
\hline & Dihydromyrcenol & 0.07 & 10,972 & 1069 \\
\hline & Terpinolene & 0.20 & 11,331 & 1084 \\
\hline \multirow{6}{*}{6} & Linalool & 2.51 & 11,633 & 1097 \\
\hline & Dehydrosabina ketone & 0.03 & 12,099 & 1117 \\
\hline & $\alpha$-Campholenal & 0.03 & 12,132 & 1119 \\
\hline & Ocimene $<$ allo- $>$ & 0.04 & 12,253 & 1123 \\
\hline & Sabinol<trans-> (trans for OH vs. IPP) & 0.11 & 12,491 & 1135 \\
\hline & Isoborneol & 0.12 & 13,102 & 1165 \\
\hline \multirow{11}{*}{7} & Methyl $m$-tolylcarbinol & 0.84 & 13,323 & 1176 \\
\hline & $\alpha$-Terpineol & 0.22 & 13,615 & 1190 \\
\hline & Cyclohexane, 1-butenylidene- & 0.35 & 13,727 & 1195 \\
\hline & 2-Isobutylideneamino-3-methylbutyronitrile & 0.09 & 13,787 & 1198 \\
\hline & Dodecane & 0.10 & 13,843 & 1201 \\
\hline & trans-Dihydrocarvone & 0.09 & 13,945 & 1206 \\
\hline & 3,5-Methanocyclopentapyrazole, 3,3a,4,5,6,6a-hexahydro-3a,4,4-trimethyl- & 0.07 & 14,124 & 1215 \\
\hline & $\begin{array}{l}\text { 1,4-Methano-1H-cyclopenta[d]pyridazine, 4,4a,5,7a-tetrahydro-8,8-dimethyl-, (1. alpha.,4. alpha.,4a. alpha.,7a. } \\
\text { alpha.)- }\end{array}$ & 0.03 & 14,350 & 1226 \\
\hline & Carvacrol, methyl ether & 0.15 & 14,687 & 1242 \\
\hline & Neral & 0.03 & 14,759 & 1248 \\
\hline & Limonen-10-ol & 0.04 & 15,400 & 1277 \\
\hline \multirow{3}{*}{8} & Thymol & 10.64 & 15,841 & 1298 \\
\hline & Carvacrol & 49.90 & 16,130 & 1313 \\
\hline & Thymol acetate & 0.08 & 16,859 & 1350 \\
\hline \multirow{3}{*}{9} & Carvacrol acetate & 0.41 & 17,205 & 1369 \\
\hline & 7-epi-Sesquithujene & 0.04 & 17,384 & 1379 \\
\hline & $\beta$-Bourbonene & 0.03 & 17,552 & 1387 \\
\hline \multirow{11}{*}{10} & E-Caryophyllene & 0.53 & 18,201 & 1422 \\
\hline & $\beta$-Gurjunene & 0.02 & 18,358 & 1435 \\
\hline & trans- $\alpha$-Bergamotene & 0.09 & 18,454 & 1443 \\
\hline & Aromadendrene $<$ allo- $>$ & 0.08 & 18,560 & 1452 \\
\hline & 3,5-Methanocyclopentapyrazole, 3,3a,4,5,6,6a-hexahydro-3a,4,4-trimethyl- & 0.03 & 18,809 & 1473 \\
\hline & D-Germacrene & 0.03 & 18,907 & 1482 \\
\hline & $\gamma$-Amorphene & 0.05 & 19,051 & 1494 \\
\hline & Neryl isobutanoate & 0.07 & 19,118 & 1500 \\
\hline & Viridiflorene & 0.15 & 19,218 & 1508 \\
\hline & Geranyl isobutanoate & 0.06 & 19,288 & 1515 \\
\hline & $\beta$-Sesquiphellandrene & 0.20 & 19,389 & 1523 \\
\hline \multirow{5}{*}{11} & $\beta$-Vetivenene & 0.49 & 19,700 & 1560 \\
\hline & $\beta$-Atlantol & 0.13 & 19,951 & 1614 \\
\hline & Methyl 11,12-octadecadienoate & 0.30 & 20,535 & 1819 \\
\hline & Tetracosane & 0.09 & 22,097 & 2402 \\
\hline & Total (identified) & & $88.75 \%$ & \\
\hline
\end{tabular}




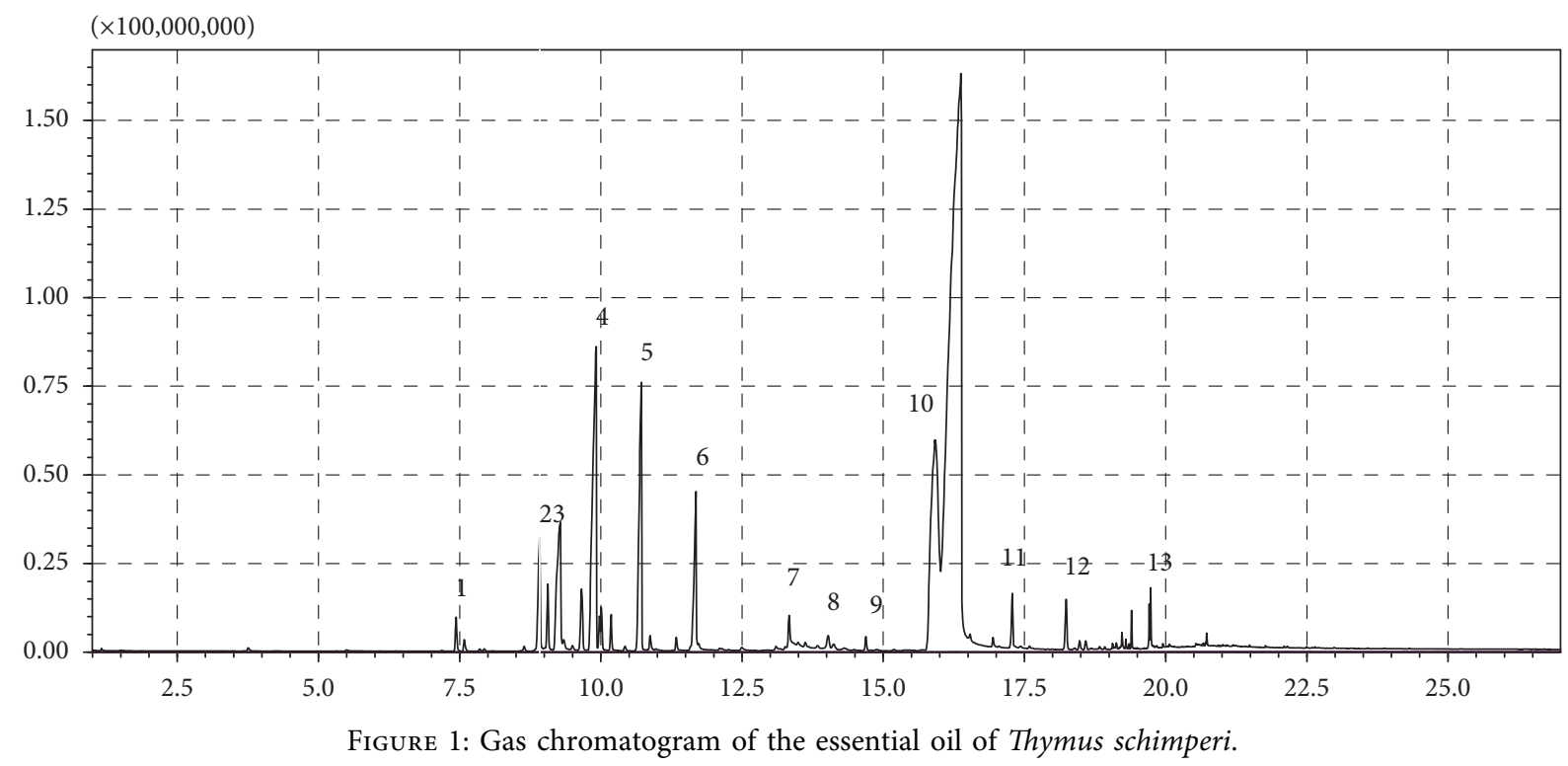

TABLE 3: Acute toxicity of single oral doses of Thymus schimperi essential oil in rats.

\begin{tabular}{|c|c|c|c|c|c|c|c|c|}
\hline Conc. (C) (mg/kg) & $\log (\mathrm{C})$ & Alive (\%) & Dead $(\%)$ & Prop., p & Corr., p & Logit $(p)$ & Probit $(p)$ & Symptoms \\
\hline 0 & & 100 & 0 & 0 & & & & None \\
\hline 300 & 2.5 & 100 & 0 & 0 & & & & None \\
\hline 600 & 2.8 & 100 & 0 & 0 & & & & None \\
\hline 900 & 3.0 & 80 & 20 & 0.2 & 0.2 & -1.4 & 3.6 & Hypoactivity, piloerection, convulsion \\
\hline 1200 & 3.1 & 80 & 20 & 0.2 & 0.2 & -1.4 & 3.6 & Hypoactivity, piloerection, convulsion \\
\hline 1500 & 3.2 & 20 & 80 & 0.8 & 0.8 & 1.4 & 6.4 & Hypoactivity, piloerection, convulsion \\
\hline \multirow[t]{6}{*}{2000} & 3.3 & 0 & 100 & 1 & & & & Hypoactivity, piloerection, convulsion \\
\hline & & & & & Slope & 11.9 & 11.9 & \\
\hline & & & & & Intercept & -37.0 & -32.0 & \\
\hline & & & & & Test value & 0.0 & 5.0 & \\
\hline & & & & & $\log (C \%)$ & 3.1 & 3.1 & \\
\hline & & & & & LD 50 & 1284.2 & 1284.2 & \\
\hline
\end{tabular}

After the dose, all rats treated were carefully examined for signs of toxicity and lethality up to $14^{\circ}$ d.Conc. (C): concentration, log (C): logarithm of the concentration, alive (\%): number of live rats in percent, and dead: number of dead rats in percent.

$260 \mathrm{mg} / \mathrm{kg}$ of essential oil orally for 28 days. Neither signs of toxicity nor deaths were observed after T. schimperi essential oil administration. T. schimperi essential oil did not result in any major changes in the body and organ weights (Table 5).

\subsubsection{Hematological and Biochemical Parameters.} Hematological evaluation has shown a significant decrement in WBC counts and increment in the MCV in the high dose group $(260 \mathrm{mg} / \mathrm{kg})$ as compared to the control group. There was no significant difference in RBC, HB, HCT, MCH, $\mathrm{MCHC}$, and PLT levels between the control group and any of the experimental groups (Table 6).

There were no significant differences in liver injury markers (ALT, AST, and ALP) between the control and any of the treatment groups. In addition, there were no significant changes in levels of blood urea and creatinine, which are indicators of kidney injury. Similarly, there was no significant difference in the levels of HDL and LDL between the control and treatment groups. Finally, electrolytes analysis revealed no significant differences in blood electrolyte levels such as sodium and potassium levels between the control and the treatment groups (Table 7).

3.2.2. Morphological Analysis. In the selected organs, the gross pathological analysis showed no observable irregularities. Furthermore, the histopathological analysis detected noticeable abnormalities in neither the control nor the treatment groups (Figures 2 and 3).

3.3. In Silico Toxicity Prediction of Compounds from the Essential Oil of T. schimperi. Toxicities of compounds from the essential oil were also tested by ADMET and vNN-ADMET servers. Toxicity and toxicological endpoint findings showed that all compounds derived from $T$. schimperi essential oil were free of h-ERG Blocker (cardiac toxicity), AMES (Ames Mutagenicity), and cytotoxicity. Regarding the hepatotoxicity parameters, most of the compounds (91.4\%) did not show any toxicity, while $8.6 \%$ of the compounds showed hepatotoxicity. Compounds that have hepatotoxicity effects are trans-sabinol, 
TABle 4: Effects of different oral single doses of Thymus schimperi essential oil in rats for acute toxicity.

\begin{tabular}{|c|c|c|c|c|c|}
\hline \multirow{2}{*}{ Parameters } & \multirow{2}{*}{ Control } & \multicolumn{4}{|c|}{ T. schimperi treatment of essential oil } \\
\hline & & $300 \mathrm{mg} / \mathrm{kg}$ & $600 \mathrm{mg} / \mathrm{kg}$ & $900 \mathrm{mg} / \mathrm{kg}$ & $1200 \mathrm{mg} / \mathrm{kg}$ \\
\hline \multicolumn{6}{|c|}{ Bodyweight loss (\%) } \\
\hline Day 7 & $5.78 \pm 0.07$ & $5.00 \pm 0.05$ & $4.71 \pm 0.03$ & $3.43 \pm 0.03^{\mathrm{a}}$ & $2.24 \pm 0.05^{\mathrm{a}}$ \\
\hline Day 14 & $10.02 \pm 0.11$ & $7.01 \pm 0.04$ & $6.30 \pm 0.04^{\mathrm{a}}$ & $5.23 \pm 0.04^{\mathrm{a}}$ & $3.85 \pm 0.05^{\mathrm{b}}$ \\
\hline \multicolumn{6}{|c|}{ Organs' weight $(g)$} \\
\hline Liver & $6.72 \pm 1.01$ & $6.71 \pm 1.08$ & $7.45 \pm 1.06$ & $7.87 \pm 0.08^{\mathrm{b}}$ & $7.91 \pm 0.09^{\mathrm{b}}$ \\
\hline Kidney & $1.52 \pm 0.04$ & $1.47 \pm 0.03$ & $1.58 \pm 0.05$ & $1.81 \pm 0.06^{\mathrm{b}}$ & $1.94 \pm 0.06^{\mathrm{b}}$ \\
\hline Heart & $0.43 \pm 0.05$ & $0.42 \pm 0.04$ & $0.40 \pm 0.03$ & $0.41 \pm 0.04$ & $0.41 \pm 0.04$ \\
\hline Spleen & $0.52 \pm 0.09$ & $0.55 \pm 0.08$ & $0.54 \pm 0.07$ & $0.55 \pm 0.08$ & $0.62 \pm 0.08^{\mathrm{a}}$ \\
\hline
\end{tabular}

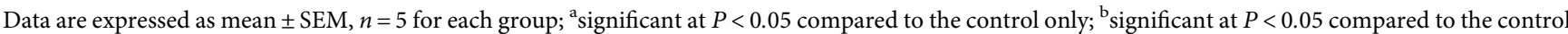
and $300 \mathrm{mg} / \mathrm{kg}$ group; ' significant at $P<0.05$ compared to the control, 600, and $9000 \mathrm{mg} / \mathrm{kg}$; ${ }^{\mathrm{d}}$ significant at $P<0.05 \mathrm{compared}$ to the $900 \mathrm{and} 1200 \mathrm{mg} / \mathrm{kg}$.

TABLE 5: Body and organ weights of rats in the control and T. schimperi essential oil-treated groups in the subacute toxicity study.

\begin{tabular}{lcccc}
\hline Parameters & Control & & Treatment of T. schimperi essential oil \\
& & $65 \mathrm{mg} / \mathrm{kg}$ & $130 \mathrm{mg} / \mathrm{kg}$ & $260 \mathrm{mg} / \mathrm{kg}$ \\
\hline Day 0 & $201.00 \pm 2.78$ & $198.00 \pm 2.22$ & $199.00 \pm 1.98$ & $198.00 \pm 2.02$ \\
Day 7 & $207.00 \pm 4.23$ & $206.00 \pm 2.50$ & $207.00 \pm 2.90$ & $202.50 \pm 2.42$ \\
Day 14 & $210.50 \pm 4.41$ & $210.00 \pm 2.61$ & $210.50 \pm 3.56$ & $205.50 \pm 2.81$ \\
Day 21 & $212.50 \pm 4.86$ & $211.00 \pm 3.67$ & $212.00 \pm 3.62$ & $211.50 \pm 4.56$ \\
Day 28 & $215.50 \pm 4.89$ & $215.00 \pm 3.45$ & & \\
Organs' weight (g) & & & & \\
Liver & $5.58 \pm 0.68$ & $6.91 \pm 0.20$ & $1.56 \pm 0.49 \pm 0.06$ & \\
Kidney & $1.47 \pm 0.15$ & $1.20 \pm 0.10$ & $0.88 \pm 0.02$ & \\
Heart & $0.85 \pm 0.06$ & $0.68 \pm 0.09$ & $0.46 \pm 0.10$ & \\
Spleen & $0.56 \pm 0.08$ & $0.47 \pm 0.09$ & $1.01 \pm 0.15$ & $0.72 \pm 0.04$ \\
Pancreas & $1.14 \pm 0.31$ & $1.00 \pm 0.20$ & $0.64 \pm 0.07$ \\
\hline
\end{tabular}

The dataareexpressed as mean $\pm \mathrm{SEM}, n=10$ for each group. There was no statistical differencebetweenthe control and theT.schimperiessential oil treatment groups $(P>0.05)$.

TABLE 6: Hematological values of rats in the control and T. schimperi essential oil-treated groups in the subacute toxicity study.

\begin{tabular}{lcccc}
\hline Parameter & Control & \multicolumn{3}{c}{ Treatment of T. schimperi essential oil } \\
& & $65 \mathrm{mg} / \mathrm{kg}$ & $130 \mathrm{mg} / \mathrm{kg}$ & $260 \mathrm{mg} / \mathrm{kg}$ \\
\hline RBC $\left(\times 10^{6} / \mu \mathrm{L}\right)$ & $8.50 \pm 0.15$ & $7.96 \pm 0.20$ & $11.80 \pm 1.50$ & $7.25 \pm 1.22$ \\
WBC $\left(\times 10^{3} / \mu \mathrm{L}\right)$ & $14.09 \pm 1.37$ & $12.94 \pm 1.04$ & $16.28 \pm 0.39$ & $7.40 \pm 1.79^{\mathrm{a}}$ \\
Hb $(\mathrm{g} / \mathrm{dl})$ & $16.70 \pm 0.31$ & $15.82 \pm 0.30$ & $48.37 \pm 1.36$ & $14.48 \pm 2.29$ \\
HCT $(\%)$ & $47.73 \pm 0.84$ & $47.98 \pm 0.69$ & $58.93 \pm 0.80$ & $41.97 \pm 7.03$ \\
MCV $(\mathrm{pg})$ & $56.13 \pm 0.49$ & $57.57 \pm 1.70$ & $20.25 \pm 0.19$ & $60.15 \pm 0.39^{\mathrm{a}}$ \\
MCH $(\mathrm{pg})$ & $19.63 \pm 0.16$ & $19.87 \pm 0.17$ & $33.70 \pm 0.33$ & $20.80 \pm 0.97$ \\
MCHC $(\mathrm{g} / \mathrm{dl})$ & $34.98 \pm 0.54$ & $32.97 \pm 0.67$ & $830.00 \pm 79.07$ & $35.68 \pm 1.46$ \\
PLT $\left(\left(\times 10^{3} / \mu \mathrm{L}\right)\right.$ & $942.00 \pm 120.50$ & $952.00 \pm 162.87$ & $804.50 \pm 156.68$ \\
\hline
\end{tabular}

The data are expressed as mean \pm SEM, $n=10$ for each group. ${ }^{a}$ Significant difference compared to the control group $(P<0.05)$. RBC: red blood cells; WBC: white blood cells; Hb: hemoglobin; HCT: hematocrit; MCV: mean corpuscular volume; MCH: mean corpuscular hemoglobin; MCHC: mean corpuscular hemoglobin concentration; PLT: platelets.

methyl m-tolyl carbinol, 2-isobutylidene amino-3-methyl butyronitrile, limonene-10-ol, and $\beta$-atlantol. Most of the compounds $(96.55 \%)$ were safe for DILI (drug-induced liver injury). However, $3.45 \%$ of the compounds (thymol acetate and carvacrol acetate) have shown DILI toxicity. In addition, most of the compounds have not shown mitochondrial membrane potential (MMP) toxicity, except thymol (Table 8).

\section{Discussion}

Various medicines of herbal origin have widely been used around the world as primary therapies for various diseases [20]. Safety is checked by conducting general preclinical toxicity experiments to detect potential toxic effects of any drug, primarily in the liver and kidneys of animals [21]. If 
TABLE 7: Blood chemistry values of rats in the control and Thymus schimperi essential oil-treated groups in the subacute toxicity study.

\begin{tabular}{|c|c|c|c|c|}
\hline \multirow{2}{*}{ Parameter } & \multirow{2}{*}{ Control } & \multicolumn{3}{|c|}{ Treatment of T. schimperi essential oil } \\
\hline & & $65 \mathrm{mg} / \mathrm{kg}$ & $130 \mathrm{mg} / \mathrm{kg}$ & $260 \mathrm{mg} / \mathrm{kg}$ \\
\hline Urea $(\mathrm{Mg} / \mathrm{dL})$ & $37.10 \pm 2.37$ & $39.97 \pm 1.37$ & $37.25 \pm 0.89$ & $40.13 \pm 1.73$ \\
\hline Creatinine $(\mathrm{Mg} / \mathrm{dL})$ & $0.30 \pm 0.01$ & $0.32 \pm 0.01$ & $0.32 \pm 0.01$ & $0.35 \pm 0.02$ \\
\hline Sodium $(\mathrm{mEq} / \mathrm{L})$ & $146.17 \pm 0.54$ & $147.33 \pm 0.56$ & $147.83 \pm 1.28$ & $146.17 \pm 0.60$ \\
\hline Potassium (mEq/LL) & $4.43 \pm 0.24$ & $3.95 \pm 0.20$ & $4.55 \pm 0.28$ & $4.43 \pm 0.46$ \\
\hline Calcium $(\mathrm{mEq} / \mathrm{L})$ & $2.33 \pm 0.15$ & $2.42 \pm 0.31$ & $2.41 \pm 0.58$ & $2.35 \pm 0.30$ \\
\hline Chloride $(\mathrm{mEq} / \mathrm{L})$ & $105.17 \pm 0.54$ & $104.17 \pm 0.54$ & $105.17 \pm 0.98$ & $104.33 \pm 0.33$ \\
\hline Phosphate (mEq/L) & $2.44 \pm 0.62$ & $2.26 \pm 0.19$ & $2.42 \pm 0.13$ & $2.38 \pm 0.15$ \\
\hline $\operatorname{ALT}(\mathrm{U} / \mathrm{L})$ & $52.38 \pm 4.56$ & $54.07 \pm 5.78$ & $65.60 \pm 3.55$ & $56.67 \pm 2.15$ \\
\hline AST (U/L) & $216.35 \pm 28.53$ & $212.73 \pm 16.28$ & $200.13 \pm 10.36$ & $183.97 \pm 13.40$ \\
\hline $\operatorname{ALP}(\mathrm{U} / \mathrm{L})$ & $76.00 \pm 10.35$ & $73.33 \pm 11.49$ & $91.00 \pm 7.23$ & $88.00 \pm 7.33$ \\
\hline Albumin $(\mathrm{g} / \mathrm{dL})$ & $4.26 \pm 0.09$ & $4.38 \pm 0.11$ & $4.44 \pm 0.15$ & $4.12 \pm 0.17$ \\
\hline Total protein $(\mathrm{g} / \mathrm{dL})$ & $5.76 \pm 0.09$ & $5.85 \pm 0.12$ & $6.12 \pm 0.18$ & $6.01 \pm 0.10$ \\
\hline Glucose $(\mathrm{mEq} / \mathrm{L})$ & $134.45 \pm 10.68$ & $117.18 \pm 23.90$ & $92.82 \pm 4.70$ & $105.72 \pm 8.23$ \\
\hline $\mathrm{HDL}(\mathrm{mg} / \mathrm{dl})$ & $35.56 \pm 2.76$ & $41.58 \pm 4.97$ & $53.63 \pm 5.28$ & $53.52 \pm 4.61$ \\
\hline LDL (mg/dl) & $20.68 \pm 3.42$ & $26.99 \pm 2.52$ & $19.32 \pm 2.23$ & $18.55 \pm 1.58$ \\
\hline
\end{tabular}

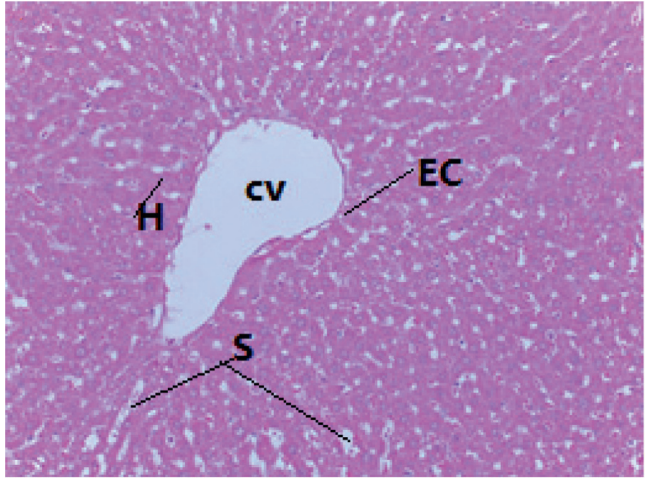

(a)

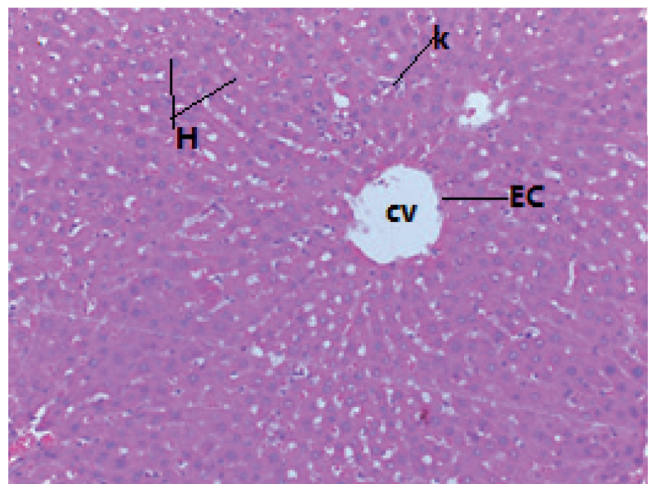

(c)

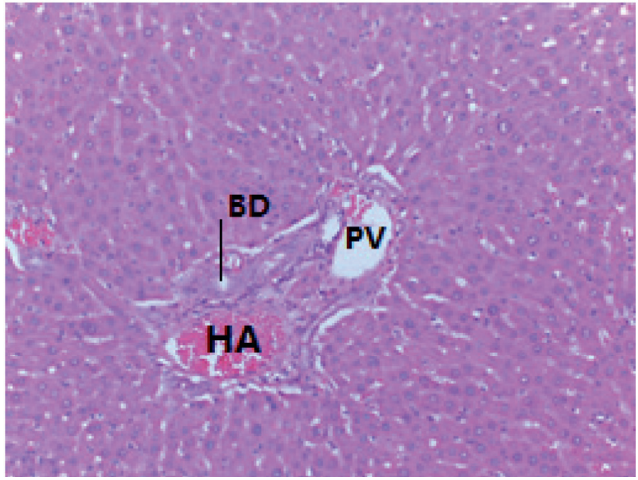

(b)

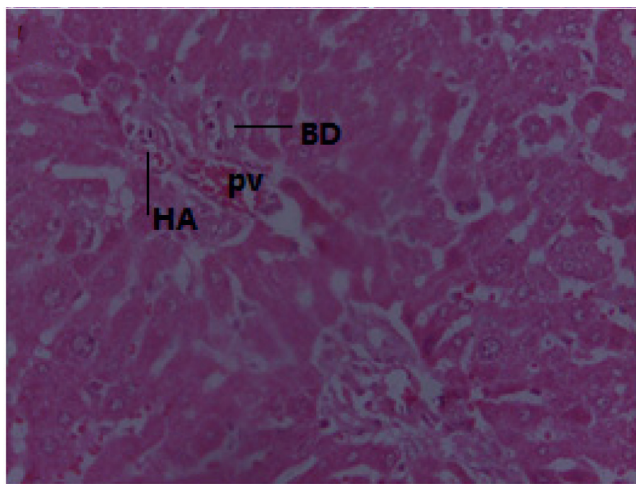

(d)

FIgURE 2: Continued. 


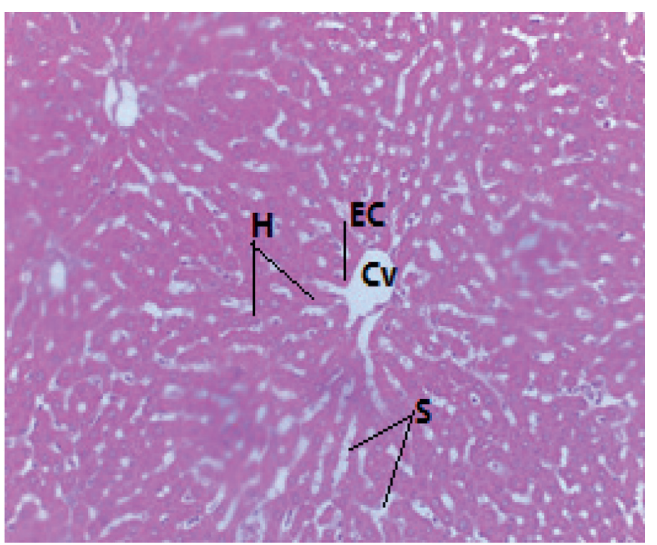

(e)

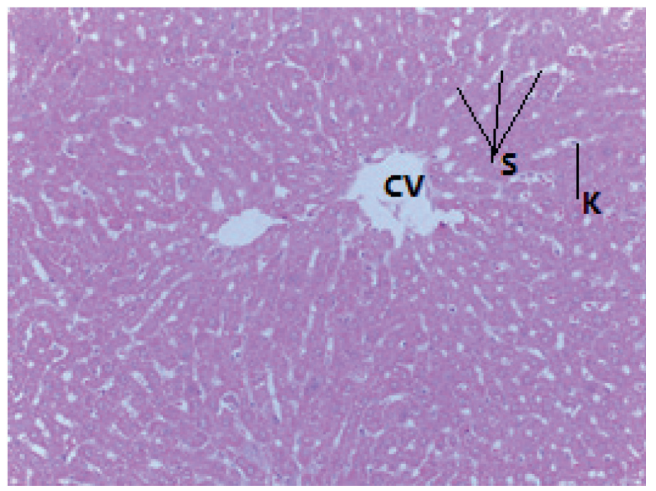

(g)

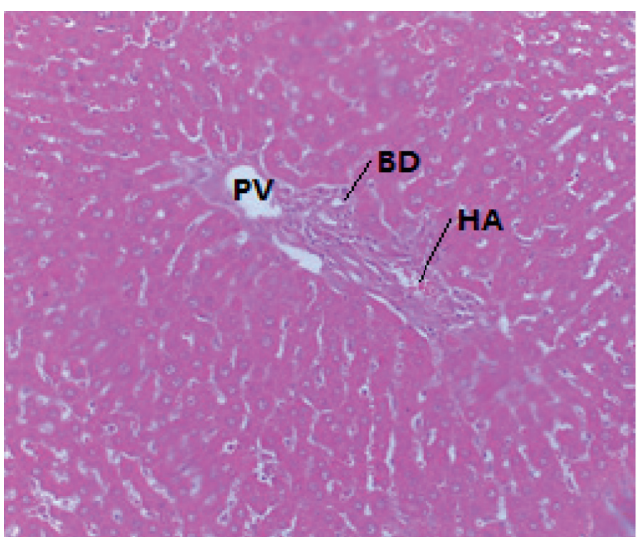

(f)

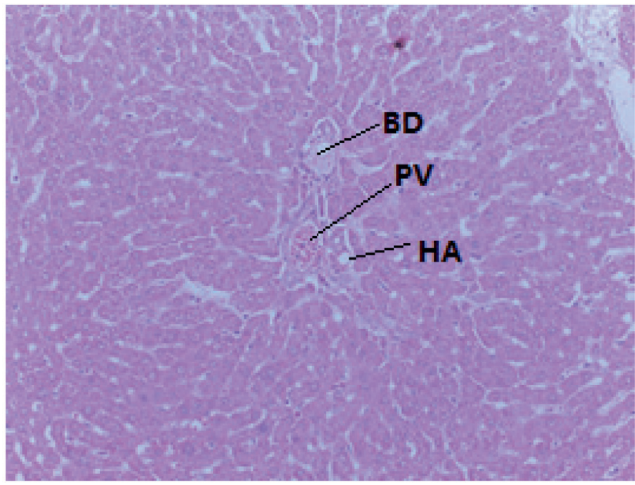

(h)

Figure 2: (a, b) Photomicrographs of liver sections of control rats; (c, d) liver sections of rats treated with $65 \mathrm{mg} / \mathrm{kg}$ of essential oil of Thymus schimperi; (e, f) liver sections of rats treated with $130 \mathrm{mg} / \mathrm{kg}$ of essential oil of Thymus schimperi; and ( $\mathrm{g}$, h) liver sections of rats treated with $260 \mathrm{mg} / \mathrm{kg}$ of essential oil of Thymus schimperi.

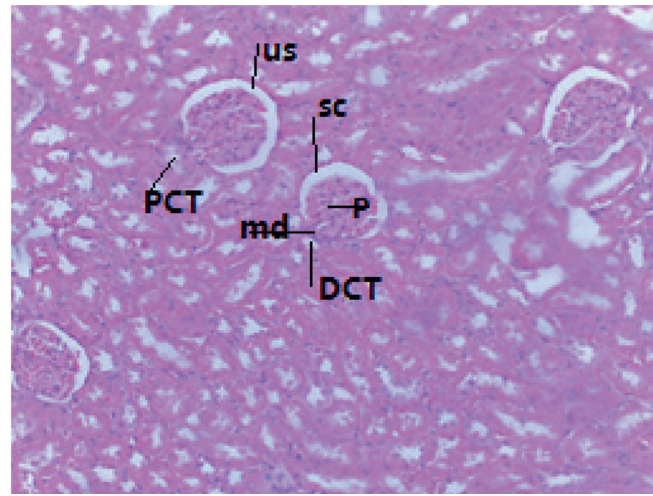

(a)

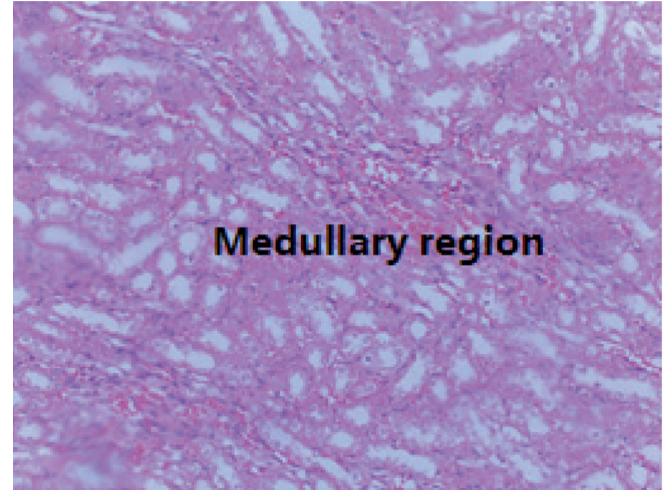

(b)

Figure 3: Continued. 


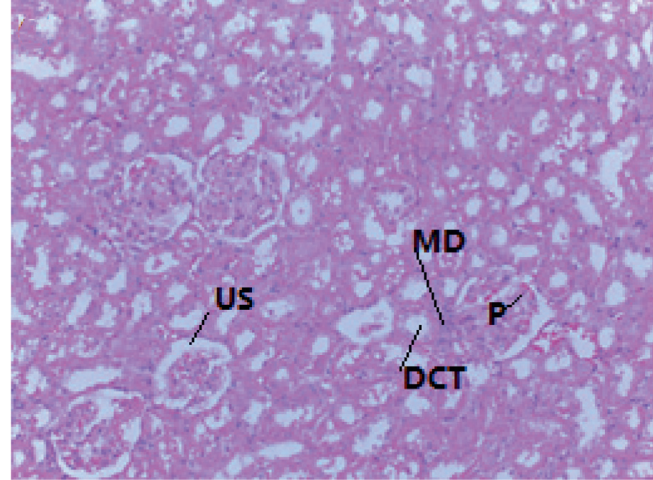

(c)

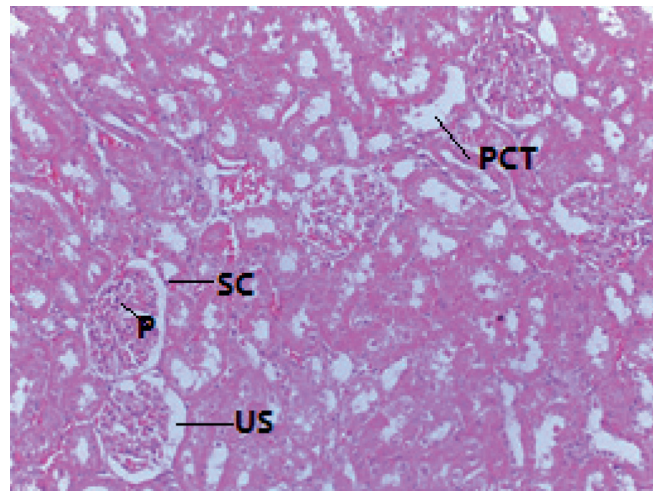

(e)

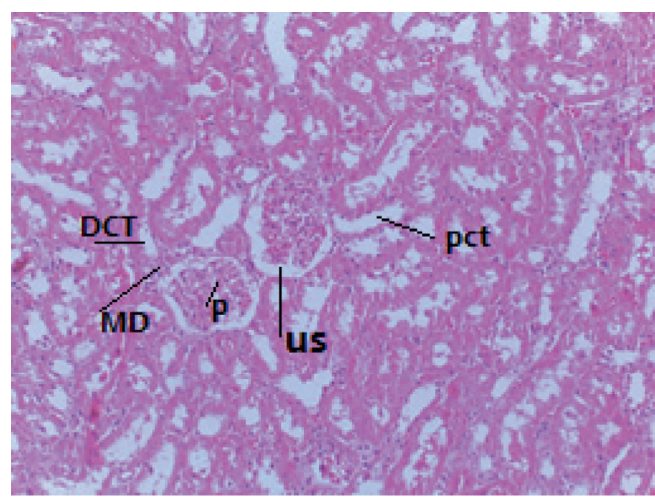

(g)

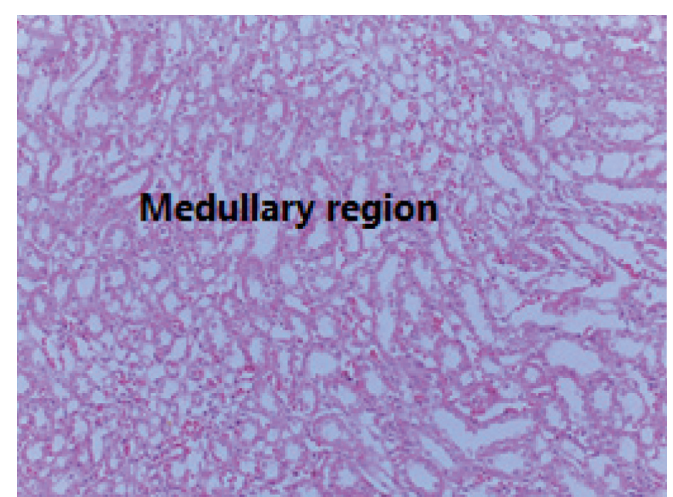

(d)

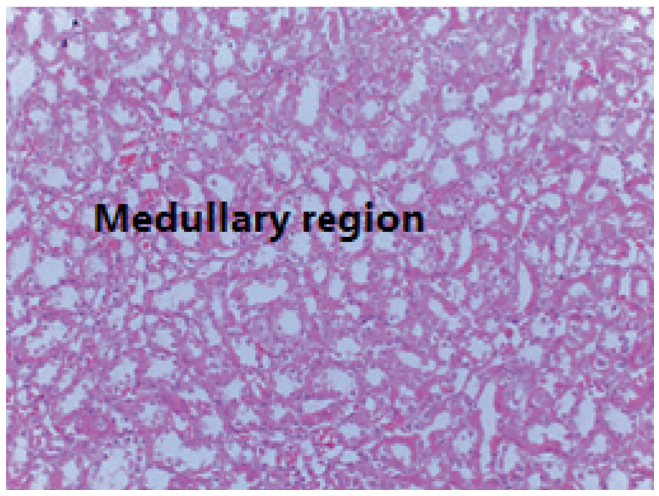

(f)

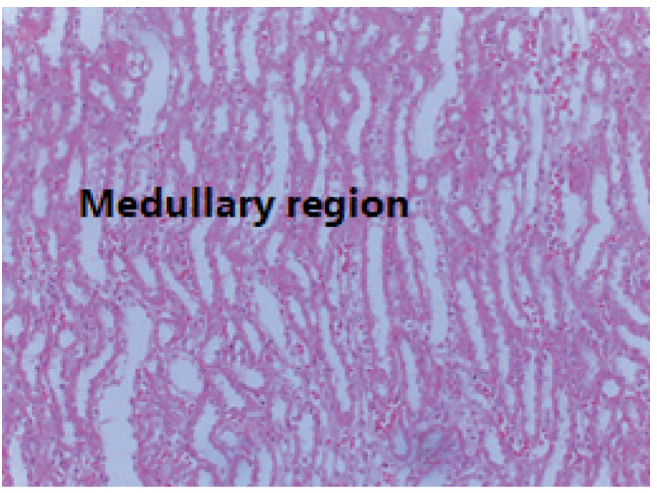

(h)

Figure 3: (a, b) Photomicrographs of the kidney sections of control rats, (c, d) kidney sections rats treated with $65 \mathrm{mg} / \mathrm{kg}$ of essential oil of Thymus schimperi, (e, f) kidney sections of rats treated with $130 \mathrm{mg} / \mathrm{kg}$ of essential oil of Thymus schimperi, and (g, h) kidney sections of rats treated with $260 \mathrm{mg} / \mathrm{kg}$ of essential oil of Thymus schimperi.

these organs are found to be mildly inflamed and damaged, the cell membrane permeability will significantly increase releasing cytoplasmic enzymes such as ALP and AST in the blood. Similarly, inflammation results in the release of mitochondrial ALT and AST $[22,23]$. Models for the toxicity screening give valuable preliminary data which can help identify natural remedies with possible health benefits [24].

Major constituents of the essential oil of T. schimperi leave were carvacrol, thymol, $O$-cymene, and $\alpha$-terpinene. The chemical composition of the oil was similar to the one previously reported by Asfaw et al. [25], which identified p-cymene, $\gamma$-terpinene, thymol, and carvacrol as major components of the oil.
In this study, using probit analysis, the $\mathrm{LD}_{50}$ of T. schimperi essential oil was found to be $1284.2 \mathrm{mg} / \mathrm{kg}$. This level of $\mathrm{LD}_{50}$ is considered moderately hazardous, in oral use, as per WHO suggestions of pesticides guidelines [26]. This finding was slightly lower than the report from a study conducted in Debre Berhan, Ethiopia $\left(\mathrm{LD}_{50}\right.$ value of $2000 \mathrm{mg} / \mathrm{kg}$ ) [27]. The possible justification for this slight discrepancy could be due to the animal model difference that in this study Wistar albino rats were used, while mice were used in the previous study. The present acute toxicity study also revealed that $T$. schimperi essential oil induced hypoactivity, piloerection, convulsion, and irregular body movements in the tested animals. This finding is consistent 
TABLE 8: In silico toxicity prediction of compounds from the essential oil of Thymus schimperi.

\begin{tabular}{|c|c|c|c|c|c|c|c|c|}
\hline \multirow[b]{2}{*}{ No. } & \multirow[b]{2}{*}{ Compounds } & \multirow{2}{*}{$\begin{array}{l}\text { Compound } \\
\text { ID }\end{array}$} & \multicolumn{6}{|c|}{ In silico toxicity } \\
\hline & & & $\begin{array}{l}\text { h-ERG } \\
\text { Blocker }\end{array}$ & HT & DILI & $\begin{array}{l}\text { Ames } \\
\text { toxicity }\end{array}$ & Cytotoxicity & MMP \\
\hline 1 & Butanoic acid, 2-methyl-, methyl ester & 13357 & No & No & No & No & No & No \\
\hline 2 & $\alpha$-Thujene & 17868 & No & No & No & No & No & No \\
\hline 3 & $\alpha$-Pinene & 6654 & No & No & No & No & No & No \\
\hline 4 & 1,3,5-Cycloheptatriene, 7-ethyl- & 561243 & No & No & No & No & No & No \\
\hline 5 & Camphene & 6616 & No & No & No & No & No & No \\
\hline 6 & $\beta$-Pinene & 440967 & No & No & No & No & No & No \\
\hline 7 & 2,3-Diazabicyclo-[2.2.2] oct-2-ene & 145130 & No & No & No & No & No & No \\
\hline 8 & 3-Octanone & 11527 & No & No & No & No & No & No \\
\hline 9 & Myrcene & 31253 & No & No & No & No & No & No \\
\hline 10 & 3-Octanol & 246728 & No & No & No & No & No & No \\
\hline 11 & $\alpha$-Phellandrene & 443160 & No & No & No & No & No & No \\
\hline 12 & $\gamma$-3-Carene & 26049 & No & No & No & No & No & No \\
\hline 13 & Cymene<ortho-> & 10703 & No & No & No & No & No & No \\
\hline 14 & D-Limonene & 440917 & No & No & No & No & No & No \\
\hline 15 & Cineole $<1,8->$ & 2758 & No & No & No & No & No & No \\
\hline 16 & B-Ocimene<(Z) & 5320250 & No & No & No & No & No & No \\
\hline 17 & $\alpha$-Terpinene & 7462 & No & No & No & No & No & No \\
\hline 18 & Terpinene<gamma-> & 7461 & No & No & No & No & No & No \\
\hline 19 & Dihydromyrcenol & 29096 & No & No & No & No & No & No \\
\hline 20 & Terpinolene & 11463 & No & No & No & No & No & No \\
\hline 21 & Linalool & 6549 & No & No & No & No & No & No \\
\hline 22 & Sabina ketone $<$ dehydro- $>$ & 527426 & No & No & No & No & No & No \\
\hline 23 & $\alpha$-Campholenal & 249978459 & No & No & No & No & No & No \\
\hline 24 & Ocimene $<$ allo- $>$ & 5368821 & No & No & No & No & No & No \\
\hline 25 & Sabinol $<$ trans $->($ trans for $\mathrm{OH}$ vs. IPP $)$ & 564260 & No & Yes & No & No & No & No \\
\hline 26 & Isoborneol & 64685 & No & No & No & No & No & No \\
\hline 27 & Methyl m-tolyl carbinol & 110953 & No & Yes & No & No & No & No \\
\hline 28 & $\alpha$-Terpineol & 442501 & No & No & No & No & No & No \\
\hline 29 & Cyclohexane, 1-butenylidene- & 556287 & No & No & No & No & No & No \\
\hline 30 & 2-Isobutylideneamino-3-methylbutyronitrile & 573025 & No & Yes & No & No & No & No \\
\hline 31 & Dodecane & 8182 & No & No & No & No & No & No \\
\hline 32 & Dihydrocarvone $<$ trans- $>$ & 24473 & No & No & No & No & No & No \\
\hline 33 & $\begin{array}{c}\text { 3,5-Methanocyclopentapyrazole, 3,3a,4,5,6,6a-hexahydro- } \\
\text { 3a,4,4-trimethyl- }\end{array}$ & 564375 & No & No & No & No & No & No \\
\hline 34 & $\begin{array}{c}\text { 1,4-Methano-1H-cyclopenta[d]pyridazine, 4,4a,5,7a- } \\
\text { tetrahydro-8,8-dimethyl-, (1. alpha.,4. alpha.,4a. alpha.,7a. } \\
\text { Alpha.)- }\end{array}$ & 562380 & No & No & No & No & No & No \\
\hline 35 & Carvacrol, methyl ether & 80790 & No & No & No & No & No & No \\
\hline 36 & Neral & 643779 & No & No & No & No & No & No \\
\hline 37 & Limonen-10-ol & 527143 & No & Yes & No & No & No & No \\
\hline 38 & Thymol & 6989 & No & No & No & No & No & Yes \\
\hline 39 & Carvacrol & 10364 & No & No & No & No & No & No \\
\hline 40 & Thymol acetate & 241091509 & No & No & Yes & No & No & No \\
\hline 41 & Carvacrol acetate & 80792 & No & No & Yes & No & No & No \\
\hline 42 & Sesquithujene $<7$-epi- $>$ & 56927990 & No & No & No & No & No & No \\
\hline 43 & $\beta$-Bourbonene & 324224 & No & No & No & No & No & No \\
\hline 44 & Caryophyllene (E-) & 5281515 & No & No & No & No & No & No \\
\hline 45 & $\beta$-Gurjunene & 6450812 & No & No & No & No & No & No \\
\hline 46 & trans-Alpha-bergamotene & 6429302 & No & No & No & No & No & No \\
\hline 47 & Aromadendrene $<$ allo- $>$ & 91746537 & No & No & No & No & No & No \\
\hline 48 & $\begin{array}{c}\text { 3,5-Methanocyclopentapyrazole, 3,3a,4,5,6,6a-hexahydro- } \\
\text { 3a,4,4-trimethyl- }\end{array}$ & 564375 & No & No & No & No & No & No \\
\hline 49 & Germacrene D & 5317570 & No & No & No & No & No & No \\
\hline 50 & Amorphene $<$ gamma- $>$ & 12313019 & No & No & No & No & No & No \\
\hline 51 & Neryl isobutanoate & 87203412 & No & No & No & No & No & No \\
\hline 52 & Viridiflorene & 10910653 & No & No & No & No & No & No \\
\hline
\end{tabular}


TABLE 8: Continued.

\begin{tabular}{|c|c|c|c|c|c|c|c|c|}
\hline \multirow[b]{2}{*}{ No. } & \multirow[b]{2}{*}{ Compounds } & \multirow{2}{*}{$\begin{array}{l}\text { Compound } \\
\text { ID }\end{array}$} & \multicolumn{6}{|c|}{ In silico toxicity } \\
\hline & & & $\begin{array}{l}\text { h-ERG } \\
\text { Blocker }\end{array}$ & $\mathrm{HT}$ & DILI & $\begin{array}{l}\text { Ames } \\
\text { toxicity }\end{array}$ & Cytotoxicity & MMP \\
\hline 53 & Geranyl isobutanoate & 5365991 & No & No & No & No & No & No \\
\hline 54 & $\beta$-Sesquiphellandrene & 519764 & No & No & No & No & No & No \\
\hline 55 & $\beta$-Vetivenene & 14475467 & No & No & No & No & No & No \\
\hline 56 & $\beta$-Atlantol & 181580 & No & Yes & No & No & No & No \\
\hline 57 & Tetracosane & 12592 & No & No & No & No & No & No \\
\hline
\end{tabular}

Toxicity profiles of compounds were analyzed using ADME web server (https://admet.scbdd.com) and vNN-ADMET web server. hERG: human ether-àgogo-related gene, HT: hepatotoxicity, and DILI: drug-induced liver injury.

with a study done by Dires et al. [27], which reported that administration of a single oral dose of the essential oil of T. schimperi causes signs of toxicity, such as hypoactivity, piloerection, and convulsion that may have resulted from disruptions in the activity of the autonomic nervous system (ANS) and the central nervous system (CNS). In an acute toxicity study, T. schimperi essential oil induced a substantial drop in body weight at higher doses which may be linked with the adverse symptoms causing the rats to become anorectic [28]. In the current study, the increment in the weight of the kidneys and the liver is most likely due to edema [29].

The hematological system is susceptible to toxic chemicals and can be used as a significant index for detecting human and animal physiological changes [30]. Hematological tests can quickly show physiological changes in the body, and the blood sample usually provides valuable information on the body's reaction to injury or disease, hunger, and stress [31]. The extent of the toxic effect of drugs and/or plant extracts can therefore be determined by evaluation of hematological parameters [32].

In the current study, there was a significant decrease in the mean white blood cell (WBC) count at a dose of $260 \mathrm{mg} / \mathrm{kg}$ as compared to the rats in the control group. This could be due to the effects of the major bioactive compounds in T. schimperi essential oil, like carvacrol and thymol, and which could cause cell cycle to arrest in the sub-G0/G1 phase, cellular apoptosis, and cell proliferation $[33,34]$. There was also an increment in the mean corpuscular volume (MCV), the index that helps to determine the size of erythrocytes, at a dose of $260 \mathrm{mg} / \mathrm{kg}$. This could be because any substance that affects cellular DNA biosynthesis, either directly or indirectly, can cause macrocytic changes. MCV elevation is a sign of alterations in DNA biosynthesis [35]. A previous study indicated that carvacrol inhibits DNA synthesis [36].

In the toxicological assessment, biochemical parameters play a significant role as markers due to their response to clinical signs and symptoms caused by toxicants. Assessment of liver and kidney function has paramount importance to determine the toxic properties of extracts and drugs [37]. In the present study, treatment of the animals with T. schimperi essential oil did not result in a significant change of all biochemical parameters. Any damage to the liver causes both ALT and AST to rise in the blood and could be taken as the first sign of the damage [37]. Creatinine level is known as a strong measure of renal function. An increase in creatinine means that there is noticeable harm to functioning nephrons $[37,38]$. AST is primarily found in red blood cells, cardiac and skeletal muscles, and the kidneys. AST is not as specific to the liver as ALT. In the present study, the mean values of ALT and ALP in treatment groups increased, while AST decreased across treatment groups compared to control; however, the changes were not statistically significant. This result was found to be consistent with a reported data from a similar study previously conducted on the same plant from Ethiopia [27]. In addition, the constituents of the essential of T. schimperi did not show any cardiac toxicity (h-ERG Blocker), AMES (Ames Mutagenicity), and cytotoxicity by ADMET and vNN-ADMET toxicity prediction servers. Another justification for these results might be that there are very few compounds that can cause hepatotoxicity or druginduced liver injury, as revealed by in silico toxicity studies (8.6\% of the total compounds were hepatotoxic, and only $3.45 \%$ were caused by drug-induced liver injury and only thymol had potential toxicity to the mitochondrial membrane toxicity).

Plasma urea measurement has been used for many years as a marker of renal function. Plasma urea is usually increased in acute and chronic kidney disease. Urea removal falls as the kidney fails and, as a result, urea tends to accumulate with diseased kidneys that are unable to excrete these substances at normal rates; this will increase the level of urea in the blood $[37,39]$. The average adult rat serum urea was measured approximately $15-45 \mathrm{mg} / \mathrm{dl}$ [40]. In the present study, mean urea values were shown to be slightly increased at doses of $65 \mathrm{mg} / \mathrm{kg}$ and $260 \mathrm{mg} / \mathrm{kg}$, although not significant, and were not associated with histopathological changes in the kidneys.

Creatinine is formed in an endogenous manner and released at a constant rate into body fluids, and its plasma concentration is mainly controlled by glomerular filtration. As a result, both plasma concentration and its renal clearance were used as measures of the glomerular filtration rate [41]. The mean amount of creatinine in the current study showed a slight increase but was not significant. In adult rats, the reference value for creatinine is around $0.2-0.8 \mathrm{mg} / \mathrm{dL}$ [42]. The measurement in this analysis was within the reference value and was supported by a lack of histopathological changes in the kidneys.

The increment of total serum protein is caused by a change in plasma water volume and an increase in plasma concentrations of one or more different proteins. Decreased 
plasma water volume is observed in cases of dehydration due to inadequate water intake or excessive water loss, such as severe vomiting or diarrhea [41]. The standard value of total protein in adult rat serum is $5.6-7.6 \mathrm{mg} / \mathrm{dL}$ [40]. Throughout the treatment groups, the overall protein levels were slightly higher when compared to the control, but it was not statistically significant. The mean total protein values for rats were within the normal range.

Lipid profile is the term given for the evaluation of total cholesterol, triglycerides, lipoproteins of high density (HDL), and lipoproteins of low density (LDL). This test is commonly used to diagnose hyperlipidemia, a risk factor for heart disease [43]. However, the results of this study did not show a significant change in any of the components listed above. This finding was also supported by the result that all compounds extracted from T. schimperi essential oil were found to be free of h-ERG Blocker (cardiac toxicity) through ADMET and vNN-ADMET toxicity prediction servers.

The electrolytes found in blood and other body fluids are sodium and potassium. They help maintain the body's water and electrolyte balance and are also important for the proper functioning of the nerves and muscles. The hormone aldosterone controls the levels of sodium and potassium in the body. These electrolytes do not have significant changes based on the findings of this study. They are also within the normal range, in both treated and control groups.

Histopathological evaluations provide information on biochemical and hematological parameters to be improved [44]. Compared to controls, the general architecture of the liver, the appearance of the hepatocytes, the hepatic sinusoids, the portal triads, and the central veins are normal. Furthermore, compared to the control, the general histological architecture was not compromised in any of the treatment groups. The no-significant change of histopathological parameters of the liver between the control animals and the test animals after 4 weeks of treatment indicates that the essential oil did not cause adverse toxic effects or hepatic damage to the liver, and this result is consistent with other studies [27, 45].

In kidney histopathology analysis, rats treated with the essential oil showed no significant difference compared to controls. The sections of the treated rat kidneys displayed normal general renal structure and the regular presence of glomeruli and tubules. The proximal tubules, the distal tubules, and the macula densa were normal. The finding was further confirmed by the values of the blood's biochemical parameters (such as urea, creatinine, and total protein), which are the principal markers of kidney damage [46]. This was consistent with the previous study, which stated that there was no difference in tissue morphology between the control group and treatment groups [27].

In addition to the in vivo toxicity study on animal models, the toxicity profile of all the compounds of T. schimperi essential oil was also evaluated by ADMET and vNN-ADMET servers [19,47]. Constituents of T. schimperi essential oil safety and toxicological findings showed that h-ERG Blocker (cardiac toxicity), AMES (Ames Mutagenicity), and cytotoxicity are free of toxicity. Regarding the hepatotoxicity parameter, most of the compounds (91.4\%) did not show toxicity, although hepatotoxicity was seen in $8.6 \%$ of the compounds (trans-sabinol, methyl $m$-tolyl carbinol, 2-isobutylideneamino-3-methyl butyronitrile, limonene-10-ol, and $\beta$-atlantol). Furthermore, most of the compounds (96.55\%) were safe for DILI (drug-induced liver injury); however, $3.45 \%$ (thymol acetate and carvacrol acetate) have shown DILI toxicity. Finally, most of the compounds have not shown mitochondrial membrane potential (MMP) toxicity, except thymol.

\section{Conclusion and Recommendations}

The yield of the essential oil from the aerial part of T. schimperi was found to be $1.39 \% \mathrm{v} / \mathrm{w}$. GC-MS study of the oil enables the identification of 57 compounds. Carvacrol was the major component of the essential oil, representing $49.90 \%$ followed by thymol (10.64\%). Acute toxicity study showed that the $\mathrm{LD}_{50}$ of the oil was $1284.2 \mathrm{mg} / \mathrm{kg}$. Similarly, subacute toxicity study demonstrated that the oil of T. schimperi does not adversely affect body weight, biochemical, and most hematological parameters at the tested doses, although the WBC count was significantly decreased and the MCV was significantly increased at a dose of $260 \mathrm{mg} /$ $\mathrm{kg}$. Besides, there were no signs of toxicity shown in the kidney and liver sections of the treated rats. All constituents of the essential oil of T. schimperi did not show any cardiac toxicity (h-ERG Blocker), AMES (Ames Mutagenicity), and cytotoxicity by ADMET and vNN-ADMET toxicity predictors. However, $8.6 \%$ of the compounds were hepatotoxic, and only $3.45 \%$ were caused by drug-induced liver injury, and only $1.75 \%$ has potential toxicity to the mitochondrial membrane. Based on this study, oral administration of the essential oil T. schimperi up to a dose of $130 \mathrm{mg} / \mathrm{kg}$ is not harmful. However, in the high-dose $(260 \mathrm{mg} / \mathrm{kg})$ group, the WBC count was significantly decreased and the MCV was significantly increased. In the in silico toxicity study, most of the components of the oil were found to be nontoxic, although few of the compounds showed hepatotoxicity and mitochondrial membrane potential toxicity. It is therefore essential to conduct chronic toxicity study on the essential oil as well as its components, which showed toxicity in the in silico study before using preparations containing T. schimperi essential oil as drugs.

\section{Data Availability}

All the data are included within the article.

\section{Conflicts of Interest}

The authors declare no conflicts of interest.

\section{Acknowledgments}

The authors are thankful for the financial support provided by the School of Graduate Studies of Addis Ababa University (AAU), Debre Markos University, and the Ethiopian Public Health Institute (EPHI). The authors also would like to thank the staff of the Traditional and Modern Medicine Research Directorate at EPHI and Departments of Anatomy, 
Pharmaceutical Chemistry and Pharmacognosy, and Pathology at AAU for their assistance during the study.

\section{References}

[1] D. J. Newman, G. M. Cragg, and K. M. Snader, "Natural products as sources of new drugs over the period 1981-2002," Journal of Natural Products, vol. 66, no. 7, pp. 1022-1037, 2003.

[2] R. Belaqziz, R. Harrak, A. Romane, K. Oufdou, and M. A. E. ElFels, "Antimicrobial and insecticidal activities of the endemic thymus broussonetti boiss. and thymus maroccanus ball," Records of Natural Products, vol. 4, no. 4, p. 230, 2010.

[3] D. Damtie and Y. Mekonnen, "Thymus species in Ethiopia: distribution, medicinal value, economic benefit, current status and threatening factors," Ethiopian Journal of Science and Technology, vol. 8, no. 2, pp. 81-92, 2015.

[4] E. Dagne, S. Hailu, D. Bisrat, and T. Worku, "Constituents of the essential oil of thymus schimperi," Bulletin of the Chemical Society of Ethiopia, vol. 12, no. 1, pp. 79-82, 1998.

[5] S. Demissew and N. Asfaw, "Some useful indigenous labiates from Ethiopia," Lamiales Newsl, vol. 3, pp. 5-6, 1994.

[6] A. Getahun, Some Common Medicinal and Poisonous Plants Used in Ethiopian Folk Medicine, Amare Getahun, Addis Abeba, Ethiopia, 1976.

[7] E. Seifu, "Chemical composition and microbiological quality of Metata Ayib: a traditional Ethiopian fermented cottage cheese," International Food Research Journal, vol. 20, no. 1, pp. 93-97, 2013.

[8] A. Assefa and T. Abebe, "Ethnobotanical study of wild medicinal trees and shrubs in Benna Tsemay district, Southern Ethiopia," Journal of Science \& Development, vol. 2, no. 1, pp. 17-33, 2014.

[9] B. Etana, S. Demissew, and Z. Asfaw, "Ethnobotanical study of traditional medicinal plants of Goma Wereda, Jima zone of Oromia region, Ethiopia," M. S. thesis, Addis Ababa University Institutional Repository, Addis Ababa, Ethiopia, 2010.

[10] N. D. Shimelis, S. Asticcioli, M. Baraldo, B. Tirillini, E. Lulekal, and V. Murgia, "Researching accessible and affordable treatment for common dermatological problems in developing countries. An Ethiopian experience," International Journal of Dermatology, vol. 51, no. 7, pp. 790-795, 2012.

[11] L. Panizzi, G. Flamini, P. L. Cioni, and I. Morelli, "Composition and antimicrobial properties of essential oils of four Mediterranean Lamiaceae," Journal of Ethnopharmacology, vol. 39, no. 3, pp. 167-170, 1993.

[12] J. D. Clark, G. F. Gebhart, J. C. Gonder, M. E. Keeling, and D. F. Kohn, "The 1996 guide for the care and use of laboratory animals," ILAR Journal, vol. 38, no. 1, pp. 41-48, 1997.

[13] OECD, Guidelines for the Testing of Chemicals, Organization for Economic, Paris, France, 1994.

[14] R. Randell, R. A. Ruddle, R. Thomas, and D. Treanor, "Diagnosis at the microscope: a workplace study of histopathology," Cognition, Technology \& Work, vol. 14, no. 4, pp. 319-335, 2012.

[15] S. Kim, J. Chen, T. Cheng et al., "PubChem 2019 update: improved access to chemical data," Nucleic Acids Research, vol. 47, pp. D1102-D1109, 2019.

[16] L. D. Mendelsohn, "ChemDraw 8 ultra, windows and macintosh versions," Journal of Chemical Information and Computer Sciences, vol. 44, no. 6, pp. 2225-2226, 2004.

[17] A. Daina, O. Michielin, and V. Zoete, "SwissADME: a free web tool to evaluate pharmacokinetics, drug-likeness and medicinal chemistry friendliness of small molecules," Scientific Reports, vol. 7, no. 1, Article ID 42717, 2017.

[18] J. Dong, N.-N. Wang, Z.-J. Yao et al., “ADMETlab: a platform for systematic ADMET evaluation based on a comprehensively collected ADMET database," Journal of Cheminformatics, vol. 10, no. 1, p. 29, 2018.

[19] P. Schyman, R. Liu, V. Desai, and A. Wallqvist, "vNN web server for ADMET predictions," Frontiers in Pharmacology, vol. 8, p. 889, 2017.

[20] J. Doull, Casarett And Doull's Toxicology: The Basic Science Of Poisons, McGraw-Hill, New York, NY, USA, 7th edition, 2007.

[21] B. Farzamfar, M. Abdollahi, S. Kabinezhadian et al., "Subchronic toxicity study of a novel herbal-based formulation (semelil) on dogs," DARU Journal of Pharmaceutical Sciences, vol. 16, 2008.

[22] W. Arneson and J. Brickell, "Assessment of Liver Function," in Clinical Chemistry: A Laboratory Perspective, pp. 233-266, F.A. Davis Company, Philadelphia, PA, USA, 1st edition, 2007.

[23] A. P. Hall, C. R. Elcombe, J. R. Foster et al., Assessment of Liver Function, Clinical Chemistry: A Laboratory Perspectivepp. 971-994, F.A. Davis Company, Philadelphia, PA, USA, 1st edition, 2012.

[24] N. Rosenthal and S. Brown, "The mouse ascending: perspectives for human-disease models," Nature Cell Biology, vol. 9, no. 9, pp. 993-999, 2007.

[25] N. Asfaw, H. J. Storesund, L. Skattebol, F. Tonnesen, and A. J. Aasen, "Volatile oil constituents of twoThymus species from Ethiopia," Flavour and Fragrance Journal, vol. 15, no. 2, pp. 123-125, 2000.

[26] World Health Organization, The WHO Recommended Classification of Pesticides by Hazard and Guidelines to Classification 2019, World Health Organization, Geneva, Switzerland, 2020.

[27] K. Dires, B. Mengiste, and E. Lulekal, "Evaluation of acute, sub-acute and skin irritation toxicity on essential oil of Thymus schimperi in Ankober, North Shewa, Debre Berhan, Ethiopia," Journal of Clinical Toxicology, vol. 8, no. 3, pp. 1-4, 2018.

[28] S. B. Budin, S. M. Siti Nor Ain, B. Omar, I. S. Taib, and O. Hidayatulfathi, "Acute and subacute oral toxicity of Litsea elliptica Blume essential oil in rats," Journal of Zhejiang University Science B, vol. 13, no. 10, pp. 783-790, 2012.

[29] J. H. Costa-Silva, C. R. Lima, E. J. R. Silva et al., "Acute and subacute toxicity of the Carapa guianensis Aublet (Meliaceae) seed oil," Journal of Ethnopharmacology, vol. 116, no. 3, pp. 495-500, 2008.

[30] X. Li, Y. Luo, L. Wang et al., "Acute and subacute toxicity of ethanol extracts from Salvia przewalskii Maxim in rodents," Journal of Ethnopharmacology, vol. 131, no. 1, pp. 110-115, 2010.

[31] A. Dalle Zotte, M. Cullere, A. Sartori et al., "Dietary spirulina (Arthrospira platensis) and thyme (Thymus vulgaris) supplementation to growing rabbits: effects on raw and cooked meat quality, nutrient true retention and oxidative stability," Meat Science, vol. 98, no. 2, pp. 94-103, 2014.

[32] A.-S. Oa, T. M. El-Hadiyah, and A. A. Al-Majed, "Effect of prolonged vigabatrin treatment on hematological and biochemical parameters in plasma, liver and kidney of Swiss albino mice," Scientia Pharmaceutica, vol. 70, no. 2, pp. 135-145, 2002. 
[33] W. Dai, C. Sun, S. Huang, and Q. Zhou, "Carvacrol suppresses proliferation and invasion in human oral squamous cell carcinoma," OncoTargets and Therapy, vol. 9, p. 2297, 2016.

[34] D. D. Deb, G. Parimala, S. S. Devi, and T. Chakraborty, "Effect of thymol on peripheral blood mononuclear cell PBMC and acute promyelotic cancer cell line HL-60," Chemico-biological Interactions, vol. 193, no. 1, pp. 97-106, 2011.

[35] J. M. Scott and D. G. Weir, "Drug-induced megaloblastic change," Clinics in Haematology, vol. 9, no. 3, pp. 587-606, 1980.

[36] H. Zeytinoglu, Z. Incesu, and K. Baser, "Inhibition of DNA synthesis by carvacrol in mouse myoblast cells bearing a human N-RAS oncogene," Phytomedicine, vol. 10, no. 4, pp. 292-299, 2003.

[37] M. Rahman, M. K. Siddiqui, and K. Jamil, "Effects of Vepacide (Azadirachta indica) on asp artate and al anine aminotransferase profiles in a subchronic study with rats," Human \& Experimental Toxicology, vol. 20, no. 5, pp. 243-249, 2001.

[38] N. Lameire, W. Van Biesen, and R. Vanholder, "Acute kidney injury," The Lancet, vol. 372, no. 9653, pp. 1863-1865, 2008.

[39] C. Féres, R. Madalosso, O. Rocha et al., "Acute and chronic toxicological studies of Dimorphandra mollis in experimental animals," Journal of Ethnopharmacology, vol. 108, no. 3, pp. 450-456, 2006.

[40] D. Pass and G. Freeth, "The rat," Anzccart News, vol. 6, no. 4, pp. 1-4, 1993.

[41] N. Tietz, A. Rinker, and L. Shaw, "International federation of clinical chemistry (IFCC) 2," Journal of Clinical Chemistry and Clinical Biochemistry, vol. 21, pp. 731-748, 1983.

[42] C. A. J. Delaney, Exotic Companion Medicine Handbook for Veterinarians, pp. 110-119, Zoological Education Network Lake Worth, Lake Worth, FL, USA, 2008.

[43] B. R. Zirkin and V. Papadopoulos, "Leydig cells: formation, function, and regulation," Biology of Reproduction, vol. 99, no. 1, pp. 101-111, 2018.

[44] C. A. Johnson-Delaney, Exotic Companion Medicine Handbook for Veterinarians, Wingers Publishing Incorporated, Thousand Oaks, CA, USA, 1996.

[45] N. Debelo, M. Afework, A. Debella, E. Makonnen, W. Ergete, and B. Geleta, "Assessment of hematological, biochemical and histopathological effects of acute and sub-chronic administration of the aqueous leaves extract of thymus schimperi in rats," Journal of Clinical Toxicology, vol. 6, no. 286, pp. 2161-0495, 2016.

[46] M. Loha, A. Mulu, S. M. Abay, W. Ergete, and B. Geleta, "Acute and subacute toxicity of methanol extract of Syzygium guineense leaves on the histology of the liver and kidney and biochemical compositions of blood in rats," Evidence-Based Complementary and Alternative Medicine, vol. 2019, Article ID 5702159, 15 pages, 2019.

[47] H. Van De Waterbeemd and E. Gifford, "ADMET in silico modelling: towards prediction paradise?" Nature Reviews Drug Discovery, vol. 2, no. 3, pp. 192-204, 2003. 